\title{
Does Individual Knowledge Management in Online Education Prepare Business Students for Employability in Online Businesses?
}

\author{
Ștefan Andrei Neștian ${ }^{1}\left(\mathbb{D}\right.$, Ana Iolanda Vodă ${ }^{2}\left(\mathbb{D}\right.$, Silviu Mihail Tiță ${ }^{1} \mathbb{D}$, Alexandra Luciana Guță ${ }^{1, *(\mathbb{D})}$ \\ and Elena-Sabina Turnea ${ }^{1}$ (D)
}

1 Department of Management, Marketing and Business Administration, Alexandru Ioan Cuza University of Iași, 700505 Iași, Romania; nestian@uaic.ro (Ș.A.N.); silviu.tita@uaic.ro or silviutita@yahoo.com (S.M.T.); sabina.turnea@uaic.ro or sabina.turnea@yahoo.com (E.-S.T.)

2 Social Sciences and Humanities Research Department, Institute for Interdisciplinary Research, Alexandru Ioan Cuza University of Iași, 700107 Iași, Romania; ana.voda@uaic.ro or yolanda.voda@gmail.com

* Correspondence: luciana.guta@uaic.ro or luciana_guta@yahoo.com; Tel.: +40-730-092-703

Citation: Neștian, Ș.A.; Vodă, A.I.; Tiță, S.M.; Guță, A.L.; Turnea, E.-S. Does Individual Knowledge Management in Online Education Prepare Business Students for Employability in Online Businesses? Sustainability 2021, 13, 2091. https://doi.org/10.3390/ su13042091

Academic Editor: Adela García-Aracil Received: 31 January 2021

Accepted: 12 February 2021

Published: 16 February 2021

Publisher's Note: MDPI stays neutral with regard to jurisdictional claims in published maps and institutional affiliations.

Copyright: (c) 2021 by the authors. Licensee MDPI, Basel, Switzerland. This article is an open access article distributed under the terms and conditions of the Creative Commons Attribution (CC BY) license (https:// creativecommons.org/licenses/by/ $4.0 /)$.

\begin{abstract}
Business education has been currently challenged by the fast introduction of online learning platforms for students enrolled in higher education who had been previously used only face-to-face interaction, raising questions about the sustainability of online education. This new learning environment creates a different path for students managing their knowledge, who, due to the influence of online experiences, could develop different skills with different outcomes for their chances of employment. This study analyses knowledge management of business students in an online education setting to discover its influence on students' perception of both their general employment chances, and specifically in online businesses. To conduct the study, we opted for a quantitative research design based on a questionnaire applied between November and December of 2020, which resulted in valid responses from 256 Bachelor's and Master's Degree students. In line with the research hypotheses, correlation, reliability tests and logistic regression were used to perform data analysis. The results clearly indicate that students' perception of their employment chances depend on the increasing score of knowledge acquisition, knowledge revision, conceptual change and knowledge application, independently and under the action of control variables. Additionally, knowledge application proved to be an important determinant for students' perception of their employment chances in online businesses.
\end{abstract}

Keywords: knowledge management; business students; chances of employment; online education; knowledge acquisition; knowledge sharing; knowledge revision and conceptual change; knowledge application

\section{Introduction}

The COVID-19 pandemic brought new needs to the world of education-maskwearing and keeping social distance-universities having adapted to new realities by transferring courses that had been entirely taught on-site into online environments. It has been a major change for both most professors and students, since online learning had not been the most popular form of study. Learning in this new context raised a set of specific challenges to the way students manage their learning process.

The campuses, previously functioning as communities of learners, had to be transformed into virtual communities, where both students and professors found new ways of knowledge transfer and learning by adopting a wide range of video conferencing and data exchange systems, some specially designed for education and others found suitable enough for this endeavour. According to Tarabasz et al. (2018), business students are prepared to work in the virtual environments through interacting with artificial intelligence, ubiquitous 
computing, and technology exposure [1]. The classroom of the future is well equipped with new technologies that are continuously updated [1].

Higher education has been viewed as the centre where knowledge is created and delivered to society and also as a centre of learning for society [2], and it will keep these roles even after the end of the pandemic by providing a more or less online version of its studies. However, questions arise about the sustainability of higher education, due to this sudden shift to the online version of education. Some of the challenges that higher education faces concerns aspects such as the creation and distribution of knowledge that is socially relevant and also the need to accomplish this with the anticipation of playing in a committed and proactive way regarding transformation and changes that are positive for societies [3]. In order to create, in a collaborative way, tools, transformations in society and knowledge that advances sustainability, higher education institutions are pressured to make partnerships with societal stakeholders and organizations [4]. Some of the solutions regarding higher education institutions sustainability refer to aspects such as reducing actions on the campus that are unsustainable, lowering the density of population and reduced public transportation towards the campuses, in the context of e-learning [5], and also value generated by software solutions and online platforms [6]. Other solutions regarding sustainability, in the case of higher education institutions, are to integrate issues concerning sustainability in research, curricula, outreach, and campus operations [7].

It is generally acknowledged in higher education that knowledge management plays a vital role [8], especially as it develops human resources for future employers at all operating levels; knowledge management also develops the "knowledge bases" of organizations or sectors [9]. If we consider the modern knowledge-based economy, universities are institutions that help to create knowledge workers, the latter being able to make a major contribution to the modern knowledge-based economy through knowledge transmission from student-to-student, as a primary means [10].

From a systemic perspective, knowledge management is recognized as an instrument that plays a significant role by incorporating collaborative learning where groups of learners avail the opportunity to learn together with the support of various internet-based tools and technologies [11]. This perspective on knowledge management suits perfectly the case of today's higher education, characterized by this new majoritarian focus on online studies. At the individual level, knowledge management practiced by professors and students is changed by this restructuring of their activities. The sudden shift to online education for so many students provides researchers an opportunity to better understand the occurring changes, as perceived by students, when they compare online and on-site learning experiences.

We built our analysis starting from a model of students' knowledge management put forward by Chang et al. (2013) [12], in which five dimensions define the way students manage their knowledge while studying — knowledge sharing, knowledge innovation, knowledge acquisition, knowledge application and knowledge accumulation-so we adapted this model for a sample of business students from a Romanian university ("Alexandru Ioan Cuza" University of Iași). All students in the sample are enrolled in different study programs, such as Economics, Business or Public Administration at the Faculty of Economics and Business Administration of this university. We need to mention that, since we considered knowledge acquisition and knowledge accumulation to be too similar for an unprepared respondent, we only adopted four variables from Chang et al. (2013) [12] model, and excluded knowledge accumulation. Additionally, the variable knowledge innovation was renamed and appears as knowledge revision and conceptual change, and the questions for this scale were adapted accordingly.

A special focus of our study is given to the employability of business students. Student employability has a major importance in the agendas of higher education institutions and business schools [13-15].

The argument connecting the concept of "employability" with business students' knowledge management is that employers seek graduates who possess such features like 
willingness to learn, intellect, knowledge, interpersonal and communication skills, team player skills and self-management skills [16]. A similar opinion is sustained by Dacre et al. (2007) [17], who pointed out that the skills, knowledge and attitude of a person are the "employability assets".

Further, since, in the case of business schools, the educational process was criticized due to an inadequate development of students' employability skills [18], when courses were predominantly on-site, we can raise a legitimate question about the adequacy of online studies to ensure a high probability of employability.

Situated at the interference between the field of knowledge management, business education and employability, we decided that the main research question of our study is: Have business students adapted their ways of managing knowledge for online education in a manner that supports their employment chances, in general, and especially in online businesses?

Online environments create a different perspective for students in managing their knowledge and could lead to the development of different skills, influenced by the online experience, with different outcomes for their chances of employment. The objective of this study is to analyse knowledge management of business students in an online education setting so as to discover its influence on students' perception of both their general employment chances, and specifically in online businesses. In this study, the terms "chances of employment" and "employability" are used interchangeably.

The novelty in our paper appears from several perspectives. First, the literature that we have found regarding the way that knowledge is managed by business students during online classes is poor. Instead, many sources are about knowledge management in business in general. Through this argument, the empirical results from our research will complete this gap. Second, our study compares two ways of employability for students: the classic way of getting employed (for working on site) and the online employment (for working using various IT\&C online systems). This perspective is realistic since, in these pandemic times, many companies have decided to move their working environments online [19]. Third, the analysis was made considering, together, employability, knowledge management and working environment for business students. The novelty in this last perspective consists in the connections made between these concepts.

The paper is divided into the following sections: Section 2 reviews the literature in the field; Section 3 describes the methods of analysis; Section 4 presents the core findings of the study, derived from the methods applied to collect and analyse data; Section 5 presents the interpretation of the findings, and finally, in the last sections, we draw conclusions, make recommendations and present the paper limitations and further directions for research.

\section{Literature Review}

\subsection{Knowledge Management and Business Education}

Despite being considered, as other social sciences, with less practical propensity than the field of technical higher education, economics and business administration education is strongly connected with the world of practitioners from all commercial organizations, developing and exchanging practical knowledge for providing an appropriate education to students and making them valuable graduates. The business environment is one of the leading forces in the development of our society, hence the performance required from graduate students is under constant pressure. It is considered that an integrated educational environment is needed, one that encourages both commitment to lifelong learning and creativity, if we want students to be prepared for succeeding in a knowledgebased economy [20,21].

For any student, a good academic performance is related to its level of personal development, assessed and graded by professors based on the proven acquisition of knowledge and skills. In this complex technological and relational world, the learning process is no longer a simple cycle of memorizing and applying a textbook but a complex activity, 
which requires from students' engagement in several types of educational activities, use of multiple learning sources and technologies. Putting academic performance in the context of distance learning, it is highlighted that problems that are related to geographical distance can be minimized with the help of modern communication technology, which has advanced and has provided tools for minimizing these problems, so that those who learn at a distance have means of interacting with both their classmates and instructors [22].

Today, a student's success is dependent on its ability to deal with a complex learning environment. Students learn from professors and colleagues, acquire knowledge from social interactions, share knowledge with colleagues and have the opportunity to apply the acquired knowledge in theoretical applications or in practice, develop thinking by growing more abstract, complex and sophisticated models representing concepts and phenomena, learn new concepts and revise opinions using previously learned ideas. In fact, students manage their knowledge and knowledge processing activities by acquiring knowledge, sharing knowledge, applying knowledge and constantly revising their knowledge.

In a study about facilitating university students' knowledge management performance, Chang et al. (2013) used a research instrument that measures five aspects of a student's knowledge management: knowledge sharing, knowledge innovation, knowledge acquisition, knowledge application and knowledge accumulation [12]. They suggest that knowledge sharing is concerned with the exchange among peers. Knowledge innovation describes changes in students' thinking and development of their own thinking model by reflection. Knowledge acquisition reflects students' status regarding knowledge acquisition from learning content, such as summary, notes, handouts, and website resources. Knowledge application is the students' ability to transfer knowledge across various settings, also referring to their reflection on how it could be applied [12].

In what follows, we are presenting the theoretical basis for our hypotheses.

\subsection{The Background of Hypotheses}

According to Pellegrini et al. (2020), the following are recognized as knowledge management processes: knowledge acquisition, knowledge creation, knowledge sharing (transfer), knowledge storage and knowledge application [23]. This general model might suffer modifications in particular cases. For example, in the banking system, Hanif, Malik, and Hamid (2018) have proved that the knowledge management process (that consists in knowledge acquisition, sharing and utilization) influence organizational performance [24].

In the knowledge management literature, the first stage in the processing cycle of knowledge is knowledge acquisition [25]. Knowledge acquisition refers to the process of acquiring new knowledge and building upon that knowledge when new knowledge occurs [26]. Another aspect of knowledge acquisition is related to the ability of using technology. In this complex knowledge environment, a significant problem is that knowledge should be arranged and accumulated, with continuous reflection, in order to become complete [12].

In the case of any student, the most basic form of knowledge acquisition is memorizing. This is the first step in any learning process: hearing or seeing new words and keeping them in the memory until further details increase the clarity of the meanings conveyed by the words. Students acquire knowledge from various sources: from their interactions with teachers, from the literature they have to read for classes, from practical applications performed in class or during internships, even from their colleagues. There is no doubt that students acquire both explicit and tacit knowledge in the learning process. Knowledge acquisition depends on the students' capacity to achieve knowledge by converting tacit knowledge into explicit knowledge, and explicit knowledge into tacit knowledge for acquisition purposes [11]. While tacit knowledge contains the knowing potential of an individual, explicit knowledge also includes the individuals' capacity of knowledge transfer [27]. 
Additionally, for good results in online business education, we need to transform students into active knowledge seekers and experiential learners, driven by motivation and values that require a high level of engagement and a lot more effort [28,29].

In the context of the long-term pandemic period, when studies take place online, students can create and obtain knowledge during the learning process. In this context, technological skills and adequate infrastructure are required [2]. However, they may forget part of what they have learned [30]. In order to reduce these losses, institutional help can be provided by the university's infrastructure. The knowledge acquired, gathered and created needs to be organized and stored in a database that enables unlimited access at any time.

Higher education institutions improve students' chances of employment by improving students' knowledge [31]. In this regard, employability can be achieved through the accreditation standards [31]. Education improves the necessary skills and abilities demanded by the market [32,33], and thus, contributes to students' employability. An educated student becomes more attractive for employers, and more successfully [31], while a weak linkage between education and the work environment creates difficulties for organizations in attracting employees [34].

For an exceptional match between online education and employability, Tseng, Yi and Yet (2019) consider that "curriculum developers and policy makers, especially for undergraduate education, should enhance the level of knowledge acquisition and help students build higher-order thinking skills and improve students' ability of constructing their own knowledge" [35] (pp. 21-22). Moreover, more resources should be invested in technology, especially in business simulation technology, so that students can learn from real-world situations [35] (p. 23). Martínez-Cerdà and Torrent-Sellens (2014) tried to establish a relation between learning, employment, education and e-skills factors in Europe [36]. The results proved that e-learning is one of the most important factors for professional development and employability [36]. However, online education is still very important for employability [31]. Based on a survey conducted on teachers and students that work in the online environment, it was found that both parties put emphasis on employability skills [31].

According to the above-mentioned studies, we can conclude that knowledge acquisition is the foundation of multiple other knowledge processes (knowledge sharing, revision of knowledge and conceptual change, knowledge application, etc.), being actually the first step in the process of knowledge management. The acquired knowledge is definitely a key point for getting employed (at least, theoretically). Therefore, the following two hypotheses were formulated:

Hypothesis 1a (H1a): Business students' perception of their chances of employment is positively influenced by knowledge acquisition.

Hypothesis 1b (H1b): Business students' perception of their chances of employment in online businesses is positively influenced by knowledge acquisition.

In the context of our research, knowledge sharing is defined as exchanging experiences, knowledge, and information from student to student, teacher to student and student to teacher [30]. This can be achieved by face-to-face interactions or by means of information technology, including a wide array of potential solutions, ranging from short messages to Massive Open Online Courses (MOOCs), videoconferencing or other distance learning platforms. Briefly, knowledge sharing represents a mutual exchange of thoughts in the context of social networking [37].

Cabrera and Cabrera (2002) consider technology to be one of the most important ingredients for a successful knowledge exchange, and that social environments encourage or even enforce knowledge sharing [38]. For students, sharing knowledge involves online co-learning, which implies exchanges of comments and feedback and other types of knowledge dissemination [39]. Knowledge sharing among students depends on the active and voluntary nature of knowledge sharing [40]. These knowledge exchanges among students 
help them to solve problems and gain a deeper understanding of the concepts [41]. Outcome expectations and self-efficacy are also factors that play an important role in knowledge sharing activity [37]. However, many factors, such as: physical, cultural, psychological, technological, even personality, can inhibit students not to share their personal knowledge during the learning process [40].

In a pandemic period, when social interaction is limited, education is still a more affected area than others [20]. In this context, students are not prepared to share information with others and teachers have no way of observing students' facial expressions [20]. According to a study conducted in April and May 2020 by Lup and Mitrea (2020), in which 2029 students from Romanian universities were involved, the number of those who never worked in groups increased during the pandemic from $16 \%$ to $32 \%$; ii) the percentage of those who never studied together with other colleagues increased from $18 \%$ to $35 \%$; iii) the percentage of students requesting help from colleagues decreased from $42 \%$ during face-to-face courses to $31 \%$ in online school [42]. The teachers' role in this context is to create an environment that encourages interactions between students.

Business education in the online environment is based on the interaction between learners and teachers and implies some abilities to use technology. We think that, in the case of online learning, students have a slightly higher personal motivation to follow courses. They are motivated to share their knowledge, develop friendships with other students, have self-satisfaction, or improve their own understanding of the concepts [43]. In the online environment, knowledge sharing depends on the teacher's capability to develop strategies and discussion topics related to students' interests. Good communication skills are not a guarantee of a willingness to share knowledge and does not oblige any individual to participate in knowledge sharing [44].

Students can be self-taught in the online learning process, and this can help them for employment [45]. In the online context, universities need to change the perception about students' performance and adapt their programs to the new skills required by employers. According to Seaman (2020), the most important skills requested on the labour market are flexibility, adaptability, critical thinking and problem-solving capacity [46]. To respond to these challenges, a good collaboration between students, universities and employers is needed.

Considering the previous arguments, knowledge sharing should have a positive influence in the way business students perceive their chances of employment, in general, and specifically, their chances of employment in online businesses. Therefore, the following two hypotheses were formulated:

Hypothesis 2a (H2a): There is a positive and significant correlation between business students' knowledge sharing and their perception of their chances of employment.

Hypothesis $\mathbf{2 b} \mathbf{b} \mathbf{H} \mathbf{2 b})$ : There is a positive and significant correlation between business students' knowledge sharing and their perception of their chances of employment in online businesses.

Considering that innovation in knowledge means production, creation or application processes [47], we admit that knowledge revision applied to past knowledge brings new pieces of innovation in an individual's knowledge management. In fact, knowledge creation fuels innovation and vice versa. Most of the knowledge that incorporates mistakes, namely misconceptions, leads students to new, deep understandings [25]. Conceptual change implies a revising process of small pieces from the existing understanding [48] and usually brings negations in the previous information [49]. The individuals' revision of knowledge may also appear when reading and updating thoughts [49]. Students should constantly learn new concepts and ways of applying them in practice, but this process is not only a process of knowledge acquisition, it also has an important component of questioning past knowledge as to change the conceptual perspective for accommodating new knowledge. In the cases when we see reality through a new paradigm, or when we change the mental models through which we see it, it means that we have applied generative learning [50]. 
For learning a course's content, one of the generative strategies identified by Sharp et al. (2005) [51], based on the work of Jonassen (1998), is called integration [52]. According to Guță (2014) and Sharp et al. (2005), integration refers to the integration of knowledge that is new to the existing knowledge [51,52]. We can conclude that integration implies processes of knowledge revision.

In the classroom, during an online course, or just by chatting with other colleagues, students experience knowledge revisions and conceptual changes. Students can prove that they are innovative, creative and have original thinking [32]. In particular, online learners create knowledge through analysing, appraising, and synthesizing, which, ultimately, brings about innovation [47]. In the online educational process, the individual brings innovation in knowledge, when it produces or spreads viewpoints, problem solutions, and thoughts, while interacting and collaborating with others [2,47]. Whether it is about formal or informal knowledge, students are learning through these exchanges of knowledge [49]. For this to happen, explanations and justifications of correct knowledge are required, which represent a key factor in the revision process [53].

Multiple sources of information that argue that changes in the individual beliefs lead to successful knowledge revision $[49,53]$. Thus, a complex learning environment, with multiple knowledge sources and multiple channels, should facilitate the process of knowledge revision and conceptual change.

Trevors et al. (2016) mentioned that Kendeou et al. $(2013,2014)$ stated that, according to the Co-activation Principle, there are two primary drivers that converge simultaneously and lead to knowledge revision: prior knowledge and new information [54]. These drivers need to complete each other because they integrate, in the same mental network, both correct and incorrect information, which is called the Integration Principle [54]. In our opinion, this integration ultimately brings the conceptual changes.

Online education allows students to express divergent thinking and to reflect upon multiple ideas without being (physical) in an intimidating context [55]. Thus, business institutions should invest in creating new knowledge and possibilities of transferring it into the virtual environment [56].

According to what has been discussed earlier, we could summarize that knowledge revision is a preceding step for conceptual change. Only after an individual revises their own ideas, beliefs, etc., do new mental models come up to experiment with the changes into the chances of employment in perceptions, or even in real life. However, it is obvious that, between revision of knowledge and conceptual change and employment, there is a connection, no matter whether in on-line or physical learning environment. Therefore, the following two hypotheses were formulated:

Hypothesis 3a (H3a): Business students' perception of their chances of employment is positively influenced by revision of knowledge and conceptual change.

Hypothesis $3 \mathbf{b}(\mathbf{H} 3 \mathbf{b})$ : Business students' perception of their chances of employment in online businesses is positively influenced by revision of knowledge and conceptual change.

At first glance, knowledge application should be highly related to the chances that students have to be hired, either in general, or in online businesses. This is because, when students apply the knowledge that they gained, the highest possible value is conferred to their knowledge, from an employer's point of view. Only when a person applies the knowledge that they have, we know that the person has gained relevant knowledge in a specific field.

According to Nentl and Zietlow (2008), application is the "ability to use learned material in new and concrete situations or to demonstrate the accurate use of a concept or theory in a different context" [57] (p. 162). A particular case of knowledge application for business students is the entrepreneurial activity. Applying knowledge through training can stimulate human capital, and indirectly, the entrepreneurial activities [24]. In a quantitative study about knowledge and entrepreneurship intention applied on students from 
Jakarta, it was found that entrepreneurship education impacts entrepreneurial knowledge, and entrepreneurial knowledge influences students' entrepreneurial intentions [58].

Chang et al. (2013) consider knowledge application to be the process where a person who learns utilizes the existing knowledge that he or she has [12]. In the questionnaire used by Chang et al. (2013), the scale for knowledge application measures how students apply knowledge on artifacts or how students reflect [12].

Brînză et al. (2020), in a study regarding students' perceptions in the matter of the effectiveness of the educational process and students' preparation for the tourism sector, found that, for students from the two universities on which they applied the study, collaboration of the faculties with companies from the tourism sector is more important for students than facilities that are offered by the faculties, such as modern teaching, or access to a library. In this context, the authors highlight the importance of partnerships between public and private sectors [59]. Based on Brînză et al. (2020) conclusions, we can infer that knowledge application is highly linked, for students, with the chances of being successful in the tourism sector [59]. Customizing this for the focus of our research, knowledge application ought to have a positive influence on business students' perception of their chances of employment, and respectively, of their chances of employment in online businesses.

According to Shea et al. (2005), the opportunity to increase access to higher education has been without precedent, due to online learning environments [60]. Thus, if access to higher education is made easier, with the help of online learning environments, is this correlated with the possibility of students applying their knowledge during their studies in order to improve their employability?

Considering the above-mentioned arguments, knowledge application should have a positive influence on the way business students perceive their chances of employment in general, and their chances of employment in online businesses, in particular. Therefore, the following two hypotheses were formulated:

Hypothesis 4a (H4a): Business students' perception of their chances of employment is positively influenced by knowledge application.

Hypothesis 4b (H4b): Business students' perception of their chances of employment in online businesses is positively influenced by knowledge application.

\section{Methodology and Data}

This study analyses the knowledge management of business students in online education settings to discover its influence on students' perception of both their general employment chances, and specifically, in online businesses. In order to achieve this, we intend to answer the following research questions (RQs):

RQ1: Have business students adapted their ways of managing knowledge for online education in a manner that supports their chances of employment, in general, and in online businesses, in particular?

RQ2: Have the ways of managing their knowledge during online education made business students better prepared for employability in online businesses?

\subsection{Sampling and Data Collection}

This study was conducted using a questionnaire, comprised of 53 items, which was distributed to students from the Faculty of Economics and Business Administration of the "Alexandru Ioan Cuza" University of Iași, Romania. Data was collected between November and December of 2020. The sample consists of bachelor (third year of study) and master students (first and second year of study) who were following their second semester of online studies due to the pandemic, after being originally admitted for on-site studies. We selected this sample due to the fact that final year bachelor and master students are more aware and more active in the labour market, and more concerned with their chances 
of employment. The total number of valid responses included 256 observations. In order to assure the anonymity of respondents, no personal information was collected. Details are shown in Table 1.

Table 1. Descriptive statistics of the sample.

\begin{tabular}{cccc}
\hline Variable & Category & Frequency & Percentage (\%) \\
\hline \multirow{3}{*}{ Work experience } & No experience & 50 & 19.50 \\
& Under one year & 77 & 30.10 \\
& between 1 and 3 years & 71 & 27.70 \\
Gender & over 3 years & 58 & 22.70 \\
& Females & 201 & 78.50 \\
Student category & Males & 55 & 21.50 \\
& Bachelors students & 93 & 36.30 \\
Age & Master students & 163 & 63.70 \\
& $20-25$ & 217 & 85.10 \\
& $26-35$ & 21 & 8.20 \\
Technology online & $36-50$ & 17 & 6.70 \\
usage & 1 $=$ Small extend & 4 & 1.60 \\
& 2 & 16 & 6.30 \\
& 3 & 64 & 25.10 \\
Total & 4 & 89 & 34.90 \\
& $5=$ Large extend & 82 & 32.20 \\
\hline
\end{tabular}

Source: authors' contribution.

As shown in Table 1, 19.50\% of the respondents have no working experience, $30.10 \%$ have under one year of working experience, while $50.40 \%$ of the respondents have between 1 and 3 or more years of working experience. The vast majority of our sample are females ( $78.50 \%$ of total) and aged between 20 and 25 years old ( $85.10 \%$ of total). Additionally, the majority of students considered that they have the knowledge, skills and experience needed to be used and capitalized on the technologies specific to the online learning activity.

\subsection{Selection and Description of Variables}

\subsubsection{Dependent Variables}

In this study, improvement of employment prospects (EMP) is used as a dependent variable. Students were asked to indicate whether online studies improve their chances of employment. We measured this dichotomous variable by assigning the value " 1 " if the answer was affirmative to the question, and the value " 0 ", otherwise.

Improvement of online employment prospects (EMP_ONB) is our second dependent variable. The students were asked to indicate whether online studies improved their chances of employment in an online business. The variable takes the value " 0 " if the answer is negative, and the value " 1 " is the respondents answered positively.

\subsubsection{Independent Variables}

Knowledge sharing (KS), a categorical variable that measured sharing status among peers. To measure KS, we used an adapted Chang et al. (2013) scale. The respondents were asked to indicate whether they shared their impressions and personal reflections with their colleagues or ideas and results for solving some homework/projects/assignments among others (see Table 2). KS consists of eight items used to construct the knowledge sharing dimension, and each item was measured using a five-point Likert scale ranging from 1-“total disagreement" to 5-“total agreement". 
Table 2. Construct, items and scales.

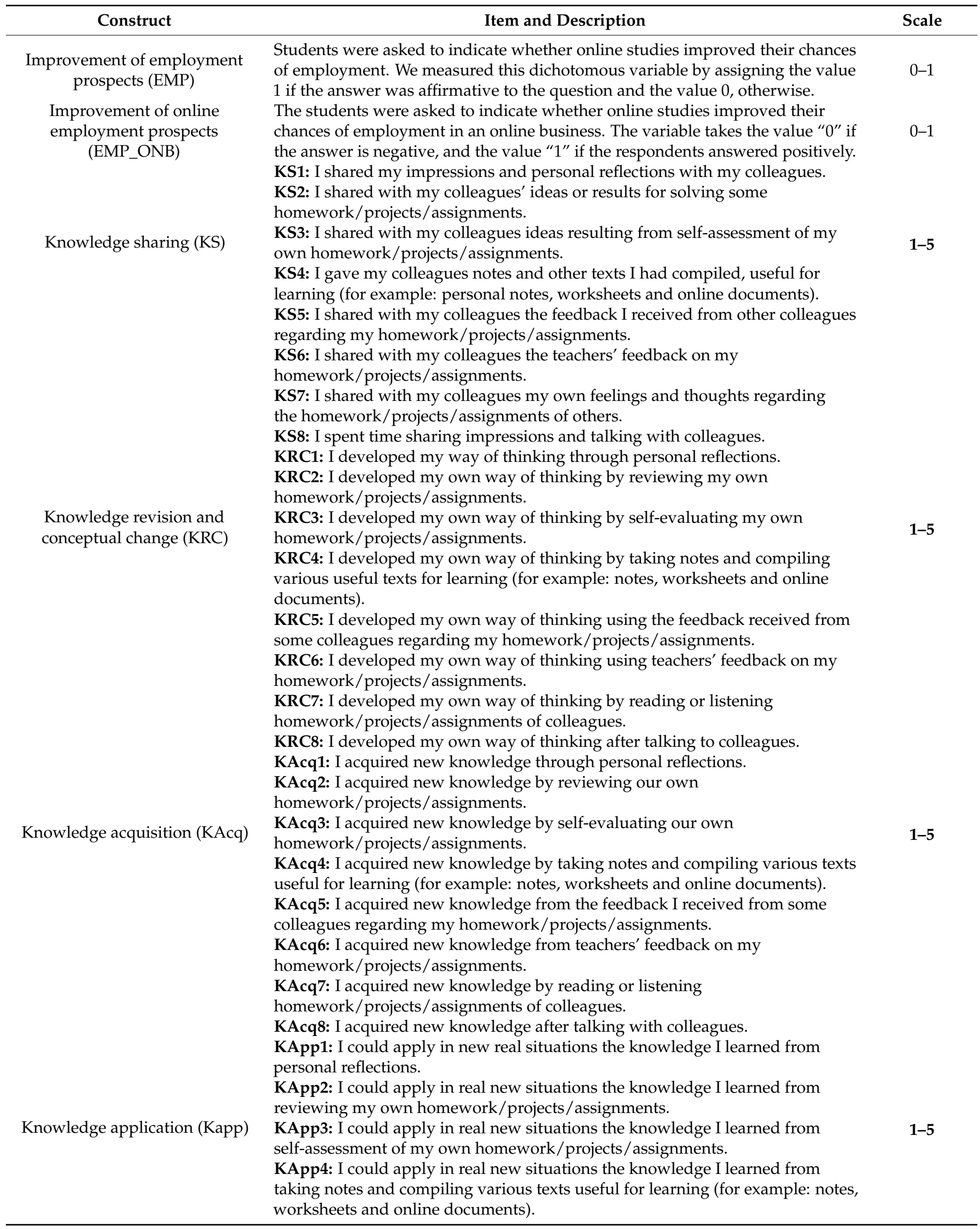


Table 2. Cont.

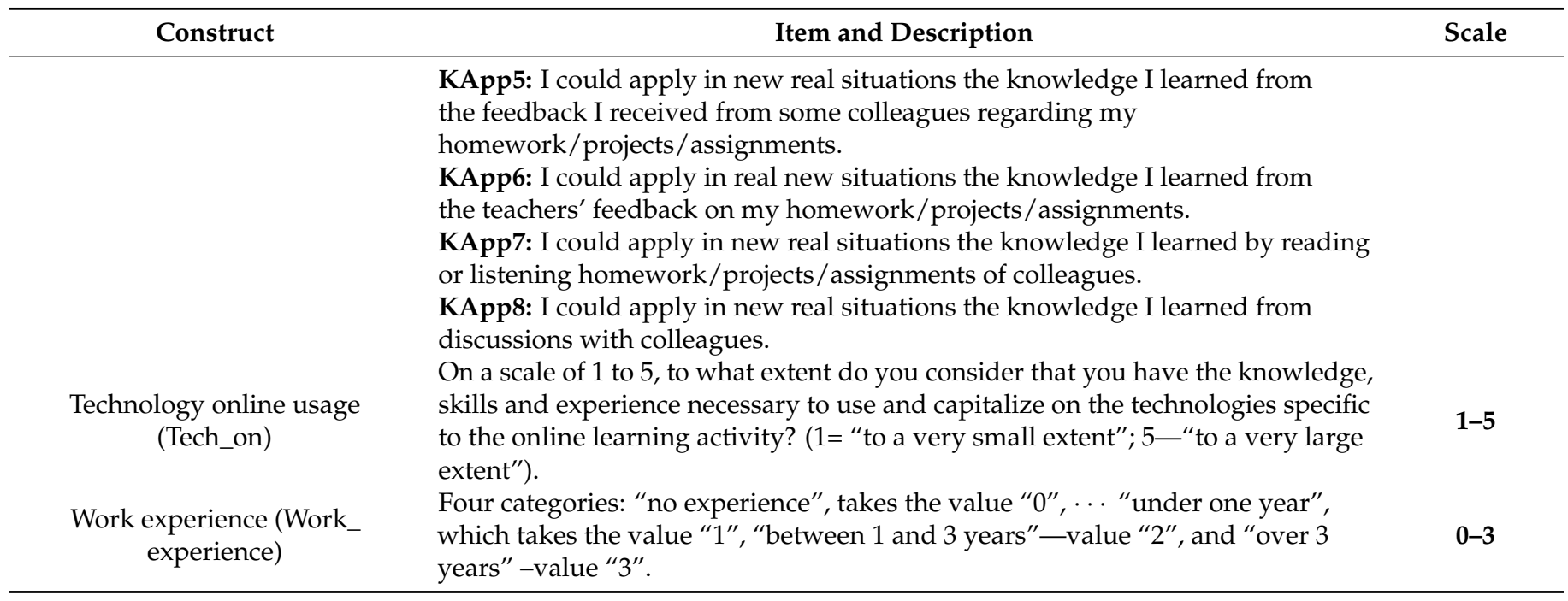

Knowledge revision and conceptual change (KRC): Eight items from Chang et al. (2013) scale were used and adapted in order to measure KRC. The respondents were asked to indicate whether they developed their way of thinking through personal reflections, by reviewing or self-evaluations of their own homework/projects/assignments, etc. KRC consists of eight items that were measured using a five-point Likert scale ranging from 1 - "total disagreement" to 5-“total agreement" (see Table 2).

Knowledge acquisition (KAcq) was measured using an adapted Chang et al. (2013) scale, which consisted of eight items used to determine the construct [12]. The students had to indicate if they acquired new knowledge through personal reflections, by reviewing their own homework/projects/assignments among others (see Table 2). The respondent answers were evaluated using a five-point Likert scale ranging from 1- "total disagreement" to 5 - "total agreement".

Knowledge application (Kapp) measured how students applied knowledge in different situations or how they reflected on it. The construct consists of eight items developed, starting from Chang et al. (2013) methodology [12]. Some of the questions included in the survey indicate if respondents could apply, in new real situations, the knowledge they learned from personal reflections or if they could apply, in real new situations, the knowledge they learned from reviewing their own homework/projects/assignments among others (see Table 2). The items were evaluated based on a Likert-scale, ranging from 1 - "total disagreement" to 5-“total agreement".

We used two control variables, as follows:

- Technology online usage (Tech_on). On a scale from 1 to 5, to what extent do you consider that you have the knowledge, skills and experience necessary to use and capitalize on the technologies specific to the online learning activity? (1= "to a very small extent"; 5- "to a very large extent").

- Work experience (Work_experience), with four answer categories: "no experience", takes the value " 0 ", "under one year", which takes the value " 1 ", "between 1 and 3 years"—value " 2 ", and "over 3 years"—value " 3 "(see Table 2).

\subsection{The Regression Model and Components Estimation}

We used logistic regression models in order to evaluate if business students adapted their ways of managing knowledge for online education in such a manner that it supported their employability, and also to establish if the ways of managing their knowledge during online education made business students better prepared for employability in online businesses. 
Several logistic regression models were used to assess the probability of an individual to belong to a specific group (dependent $=1$ ), or not (dependent $=0$ ). The models can be expressed in the following form:

$$
\operatorname{Prob}\left(Y=1 \mid X_{j}\right)=\beta_{0}+\beta_{1} \mathrm{KRC}+\beta_{2} \mathrm{KAcq}+\beta_{3} \mathrm{KApp}+\varepsilon
$$

$$
\operatorname{Prob}\left(Y=1 \mid X_{j}\right)=\beta_{0}+\beta_{1} \mathrm{KRC}+\beta_{2} \mathrm{KAcq}+\beta_{3} \mathrm{KApp}+\beta_{4} \text { Tech_on }+\beta_{5} \text { Work_experience }+\varepsilon
$$

$$
\operatorname{Prob}\left(Y^{*}=1 \mid X_{j}\right)=\beta_{0}+\beta_{1} \mathrm{KRC}+\beta_{2} \mathrm{KAcq}+\beta_{3} \mathrm{KApp}+\varepsilon
$$

$\operatorname{Prob}\left(Y^{*}=1 \mid X_{j}\right)=\beta_{0}+\beta_{1} \mathrm{KRC}+\beta_{2} \mathrm{KAcq}+\beta_{3} \mathrm{KApp}+\beta_{4}$ Tech_on $+\beta_{5}$ Work_experience $+\varepsilon$

where $\operatorname{Prob}\left(Y=1 \mid X_{j}\right)$ represents the probability of a business student to adapt their ways of managing knowledge for online education, in a manner that supports their employability, and depends on a set of explanatory variables $X_{j}$ and $\operatorname{Prob}\left(Y^{*}=1 \mid X_{j}\right)$, representing the probability that business students adapt their ways of managing their knowledge during online education, in a manner that supports their employability in online businesses, and depends on a set of explanatory variables $X_{j}$. The independent variables used in the analysis are knowledge revision and conceptual change (KRC), knowledge acquisition (KAcq) and knowledge application (Kapp). Technology online usage and work experience were used as control variables. Therefore, $\beta 1$ to $\beta 5$ represent the regression parameters estimations, $\beta 0$ is the intercept, and $\varepsilon$ is the error term. The analysis was performed using Stata.

For knowledge sharing (KS), knowledge revision and conceptual change (KRC), knowledge acquisition (KAcq) and knowledge application (Kapp), the score for the components were estimated using the following equations:

$$
\begin{aligned}
\mathrm{KS} & =\left(\sum_{i=1}^{8} \mathrm{KS}_{\mathrm{i}}\right) / 8 \\
\mathrm{KRC} & =\left(\sum_{i=1}^{8} \mathrm{KRC}_{i}\right) / 8 \\
\mathrm{KAcq} & =\left(\sum_{i=1}^{8} \mathrm{KAcq}_{\mathrm{i}}\right) / 8 \\
\mathrm{KApp} & =\left(\sum_{i=1}^{8} \mathrm{KApp}_{\mathrm{i}}\right) / 8
\end{aligned}
$$

Each independent variable was calculated as the mean of each subcomponent, $i=$ $1 \ldots, 8 ; \mathrm{KS} 1, \ldots, \mathrm{KS} 8 ; \mathrm{KRC} 1, \ldots, \mathrm{KRC} 8 ; \mathrm{KAcq} 1, \ldots, \mathrm{KAcq} 8$ and KApp1, . . , KApp8 represent the items used in the survey.

\section{Results and Interpretation}

Table 3 presents the descriptive statistics for the dependent variables and summated scales. The scales used to measure the dependent variables were binary scales $(0=$ "negative"; 1 = "positive") and 5-point Likert scales for the others (1-"total disagreement" to 5 - "total agreement"). Table 3 shows the number of items used for each construct, minimum, maximum, mean and standard deviation. 
Table 3. Descriptive statistics for the variables and summated scales.

\begin{tabular}{ccccccc}
\hline Variable & $\mathbf{n}$ & No. of Items & Min. & Max. & Mean & Std. Deviation \\
\hline $\begin{array}{c}\text { Improvement of employment prospects (EMP) } \\
\text { Improvement of online employment }\end{array}$ & 256 & 1 & 0.00 & 1.00 & 0.3477 & 0.47716 \\
prospects (EMP_ONB) & 256 & 1 & 0.00 & 1.00 & 0.6250 & 0.48507 \\
Knowledge sharing (KS) & 256 & 8 & 1.00 & 5.00 & 3.5020 & 1.00787 \\
(KRC) & 256 & 8 & 1.00 & 5.00 & 3.5957 & 0.86312 \\
Knowledge revision and conceptual change & 256 & 8 & 1.00 & 5.00 & 3.7119 & 0.86759 \\
Knowledge acquisition (KAcq) & 256 & 8 & 1.00 & 5.00 & 3.4448 & 0.92822 \\
Knowledge application (Kapp) & & & & & \\
\hline
\end{tabular}

Source: authors' contribution.

In Table 3, we can note that the means for improving the employment prospects (EMP), and improving the online employment prospects (EMP_ONB) range between 0.3477 and $0.6250(\mathrm{SD}=0.47716$; respectively $\mathrm{SD}=0.48507$ ). The highest mean is registered for knowledge acquisition (KAcq), while for the other constructs included in the analysis, it ranges between 3.4448 and 3.5957 .

Table 4 shows that knowledge revision and conceptual change (KRC), Knowledge acquisition (KAcq) and Knowledge application (Kapp) are all positively $\left(B_{\mathrm{KRC}}=0.305\right.$; $s s_{\mathrm{KAcq}}=0.250$ and $s s_{\mathrm{KApp}}=0.409$ ) and significantly correlated with EMP (business students adapting their ways of managing knowledge for online education, in a manner that supports their employability) $(p<0.01)$.

Table 4. Correlation coefficients and associated level of significance.

\begin{tabular}{|c|c|c|c|c|c|c|c|}
\hline & & EMP & EMP_ONB & KS & KRC & KAcq & KApp \\
\hline \multirow{3}{*}{ EMP } & Pearson Correlation & 1 & & & & & \\
\hline & Sig. (2-tailed) & & & & & & \\
\hline & $\mathrm{N}$ & 256 & & & & & \\
\hline \multirow{3}{*}{ EMP_ONB } & Pearson Correlation & $0.413^{* * * *}$ & 1 & & & & \\
\hline & Sig. (2-tailed) & 0.000 & & & & & \\
\hline & $\mathrm{N}$ & 256 & 256 & & & & \\
\hline \multirow{3}{*}{ KS } & Pearson Correlation & 0.093 & 0.078 & 1 & & & \\
\hline & Sig. (2-tailed) & 0.136 & 0.215 & & & & \\
\hline & $\mathrm{N}$ & 256 & 256 & 256 & & & \\
\hline \multirow{3}{*}{ KRC } & Pearson Correlation & $0.305^{* * * *}$ & $0.165^{* * * *}$ & $\begin{array}{l}0.526 \\
* * * *\end{array}$ & 1 & & \\
\hline & Sig. (2-tailed) & 0.000 & 0.008 & 0.000 & & & \\
\hline & $\mathrm{N}$ & 256 & 256 & 256 & 256 & & \\
\hline \multirow{3}{*}{ KAcq } & Pearson Correlation & $0.250 * * * *$ & $0.158^{* * *}$ & ${ }_{* * * *}^{0.533}$ & $0.829^{* * * *}$ & 1 & \\
\hline & Sig. (2-tailed) & 0.000 & 0.011 & 0.000 & 0.000 & & \\
\hline & $\mathrm{N}$ & 256 & 256 & 256 & 256 & 256 & \\
\hline \multirow{3}{*}{ KApp } & Pearson Correlation & $0.409 * * * *$ & $0.257^{* * * *}$ & $\begin{array}{l}0.415 \\
* * * *\end{array}$ & $0.699^{* * * *}$ & $0.747^{* * * *}$ & 1 \\
\hline & Sig. (2-tailed) & 0.000 & 0.000 & 0.000 & 0.000 & 0.000 & \\
\hline & $\mathrm{N}$ & 256 & 256 & 256 & 256 & 256 & 256 \\
\hline
\end{tabular}

Note: ${ }^{* * * *} p<0.01$ (2-tailed); ${ }^{* * *} p<0.05$ (2-tailed). Source: authors' contribution.

Similar results are obtained when we take into consideration EMP_ONB (managing knowledge for online education, in a manner that supports students' online employability). Knowledge revision and conceptual change (KRC), knowledge acquisition (KAcq) and knowledge application (Kapp) were also positively and significantly correlated with the dependent variable $\left(B_{\mathrm{KRC}}=0.165, \mathrm{p}<0.01 ; s s_{\mathrm{KAcq}}=0.158, \mathrm{p}<0.01\right.$ and $s s_{\mathrm{KApp}}=0.257$, $p<0.01$ ).

Given the fact that knowledge sharing (KS) was not significantly correlated with either EMP or EMP_ONB, we decided to eliminate the construct from the analysis. 
For the validity and reliability of the scale, we performed Bartlett's Test of Sphericity and Kaiser-Meyer-Olkin measure of sampling adequacy (KMO) and Cronbach's $\alpha$ (Table 5).

Table 5. Validity and reliability of the scale (KMO, Bartlett's Test of Sphericity and Cronbach's $\alpha$ ).

\begin{tabular}{ccccc}
\hline \multirow{2}{*}{$\begin{array}{c}\text { Construct } \\
\text { KMO }\end{array}$} & \multicolumn{2}{c}{ Bartlett's Test of Sphericity } & \multirow{2}{*}{ Cronbach's $\alpha$} \\
\cline { 3 - 4 } & & Chi-Square & Sig. & \\
\hline $\begin{array}{c}\text { Knowledge revision and } \\
\text { conceptual change KRC }\end{array}$ & 0.878 & 1158.279 & $0.000^{* * * *}$ & 0.897 \\
Knowledge acquisition (KAcq) & 0.865 & 1303.177 & $0.000^{* * * *}$ & 0.901 \\
Knowledge application (Kapp) & 0.910 & 1534.524 & $0.000^{* * * *}$ & 0.927 \\
Overall & 0.927 & 6884.722 & $0.000^{* * * *}$ & - \\
\hline
\end{tabular}

Note: ${ }^{* * * *} p<0.01$. Source: authors' contribution.

The Kaiser-Meyer-Olkin test measures the proportion of variance in the variables that might be caused by underlying factors. The results showed that Bartlett's test of Sphericity was significant, and KMO was greater than 0.8, which is good [61,62] (Table 5). The Cronbach's alpha coefficient for knowledge revision and conceptual change KRC is 0.897; for knowledge acquisition (KAcq), it is 0.901, while for knowledge application (Kapp), it is 0.927. All the coefficient values are above 0.897, which indicate that the items have relatively high internal consistency.

Table 6 shows the logistic regression coefficients, Wald and exponential odds ratio for the variables included in the analysis. The models were developed in order to test our assumed hypothesis. 
Table 6. Logistic regression models.

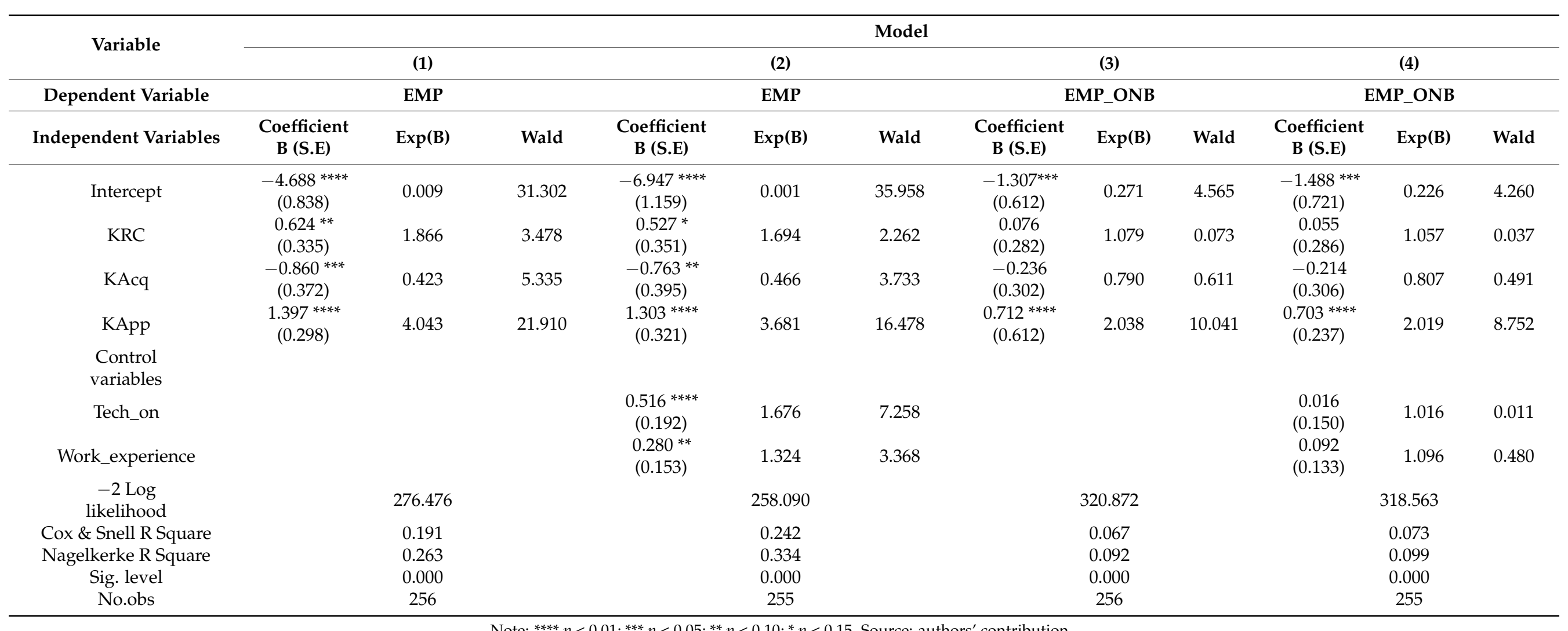


Model 1 shows that knowledge revision and conceptual change (KRC), knowledge acquisition (KAcq), and knowledge application (Kapp) have a significant impact on our dependent variable. The probability that business students adapt their ways of managing knowledge for online education, in a manner that supports their employability, increases when the score for knowledge revision and conceptual change (KRC) increase by one unit, and the scores for knowledge acquisition (KAcq) and knowledge application (Kapp) remain constant. The odds ratio was 1.866 for an additional unit to the score of knowledge revision and conceptual change (KRC), when knowledge acquisition (KAcq) and knowledge application (Kapp) showed constant variation. A similar effect on the probability that business students adapt their ways of managing knowledge for online education, in a manner that supports their employability, is given by the increasing score for knowledge application (Kapp), when the other variables included in the analysis remained constant. The odds ratio was 4.043 for an additional unit of knowledge application, when knowledge revision and conceptual change and knowledge acquisition showed constant variation. In Model 1, the dependent variable was significantly, but inversely, influenced by knowledge acquisition (KAcq). In other words, the probability that business students adapt their ways of managing knowledge for online education, in a manner that supports their employability decreases when the score for knowledge acquisition (KAcq) increases by one unit, and the scores for knowledge revision and conceptual change (KRC) and knowledge application (Kapp) remain constant.

In Model 2, we added two control variables to the analysis. The dependent variable was significantly influenced by knowledge revision and conceptual change (KRC), knowledge acquisition (KAcq), knowledge application (Kapp), technology online usage and work experience. The probability that business students adapt their ways of managing knowledge for online education, in a manner that supports their employability increases when the score for knowledge revision and conceptual change (KRC) increases by one unit and the scores for knowledge acquisition (KAcq) and knowledge application (Kapp), technology online usage and work experience remain constant. The odds ratio was of 1.694 for an additional unit to the score of knowledge revision and conceptual change (KRC) when knowledge acquisition (KAcq), knowledge application (Kapp), technology online usage and work experience showed constant variation.

Additionally, the same effect on the dependent variable is given by the increasing score for knowledge application (Kapp), when the other variables included in the analysis remained constant. In other words, the odds ratio was of 3.681 for an additional unit to the score of knowledge application (Kapp), when the scores for knowledge revision and conceptual change (KRC), knowledge acquisition (KAcq), technology online usage and work experience remained unchanged. However, the probability that business students adapt their ways of managing knowledge for online education, in a manner that supports their employability, decreases when the scores for knowledge acquisition increases by one unit, while the other variables remain constant. The odds ratio was of 0.466 for an additional unit of knowledge acquisition, when the other conditions remained unchanged. Considering a risk of $15 \%$, we can claim that the simultaneous variation of knowledge application (Kapp), knowledge revision and conceptual change (KRC), knowledge acquisition (KAcq), technology online usage and work experience significantly explain the probability that business students adapt their ways of managing knowledge for online education, in a manner that supports their employability.

In model 3, we included as dependent variable, the probability that online studies improve students' chances of employment in an online business. Evidence shows that in model 3, only knowledge application (Kapp) has a significant impact on our dependent variable. The probability that online studies improve students' chances of employment in an online business was significantly influenced by knowledge application (Kapp), with an odds ratio of 2.038 (Table 6).

In model 4, we added technology online usage and work experience as control variables. The results indicate that only knowledge application, positively and significantly 
influences our dependent variable. In other words, the odd ratio was of 2.019 for an additional unit to the score of knowledge application (Kapp), when the scores for knowledge revision and conceptual change (KRC), knowledge acquisition (KAcq), technology online usage and work experience remained unchanged.

In both models 2 and 4, Cox \& Snell R Square and Nagelkerke R Square values have increased, meaning that the models better explain the output, once the control variables were included into the analysis.

In Table 7, we synthetized how students from the Faculty of Economics and Business Administration have adapted to online courses and seminars, to changing their knowledge, learning behaviors and employment perspectives.

Table 7. Validation of hypotheses.

\begin{tabular}{|c|c|c|c|}
\hline Hypothesis & Description & Method & Hypothesis Testing Results \\
\hline Hypothesis 1a (H1a) & $\begin{array}{l}\text { Business students' perception of their } \\
\text { chances of employment is positively } \\
\text { influenced by knowledge acquisition. }\end{array}$ & \multirow[t]{2}{*}{ Logistic regression } & H1a rejected \\
\hline Hypothesis $1 \mathrm{~b}(\mathrm{H} 1 \mathrm{~b})$ & $\begin{array}{l}\text { Business students' perception of their } \\
\text { chances of employment in online } \\
\text { businesses is positively influenced by } \\
\text { knowledge acquisition. }\end{array}$ & & $\mathrm{H} 1 \mathrm{~b}$ rejected \\
\hline Hypothesis 2a (H2a) & $\begin{array}{l}\text { There is a positive and significant } \\
\text { correlation between business students' } \\
\text { knowledge sharing and their perception of } \\
\text { their chances of employment. }\end{array}$ & \multirow[t]{2}{*}{ Pearson correlation } & $\mathrm{H} 2 \mathrm{a}$ rejected \\
\hline Hypothesis 2b (H2b) & $\begin{array}{l}\text { There is a positive and significant } \\
\text { correlation between business students' } \\
\text { knowledge sharing and their perception of } \\
\text { their chances of employment in online } \\
\text { businesses. }\end{array}$ & & $\mathrm{H} 2 \mathrm{~b}$ rejected \\
\hline Hypothesis 3a (H3a) & $\begin{array}{l}\text { Business students' perception of their } \\
\text { chances of employment is positively } \\
\text { influenced by revision of knowledge and } \\
\text { conceptual change. }\end{array}$ & \multirow[t]{4}{*}{ Logistic regression } & H3a accepted \\
\hline Hypothesis 3b (H3b) & $\begin{array}{l}\text { Business students' perception of their } \\
\text { chances of employment in online } \\
\text { businesses is positively influenced by } \\
\text { revision of knowledge and conceptual } \\
\text { change. }\end{array}$ & & $\mathrm{H} 3 \mathrm{~b}$ rejected \\
\hline Hypothesis 4a (H4a) & $\begin{array}{l}\text { Business students' perception of their } \\
\text { chances of employment is positively } \\
\text { influenced by knowledge application. }\end{array}$ & & H4a accepted \\
\hline Hypothesis 4b (H4b) & $\begin{array}{l}\text { Business students' perception of their } \\
\text { chances of employment in online } \\
\text { businesses is positively influenced by } \\
\text { knowledge application. }\end{array}$ & & H4b accepted \\
\hline
\end{tabular}

Source: authors' contribution.

Our results indicate that sharing knowledge with colleagues is not correlated with either employment in online business (Sig. $=0.215$; Sig. $>0.05$ ) or with employment in general (Sig. = 0.136; Sig. > 0.05), thus rejecting hypotheses H2a and H2b (details in Tables 4 and 7).

The logistic regression models reveal that business students' perception on their chances of employment is negatively and significantly influenced by knowledge acquisition. In other words, hypothesis H1a has been rejected. In the context of online employment, no significant results have been found, thus rejecting H1b (details in Tables 6 and 7). The logistic regressions also indicate that revision of knowledge and conceptual change represents an important determinant that positively and significantly influences business 
students' perception on their chances of employment, therefore validating hypothesis $\mathrm{H} 3 \mathrm{a}$. In terms of online business employment, revision of knowledge and conceptual change does not represent a significant determinant and thus $\mathrm{H} 3 \mathrm{~b}$ is rejected. The results also indicate that business students' perception on their chances of employment in general, and in online business in particular, are positively influenced by knowledge application, thus validating hypotheses H4a and H4b (details in Tables 6 and 7).

\section{Discussion}

While technology is considered to be one of the most important ingredients for a successful knowledge exchange, and that social environments encourage or even enforce knowledge sharing [38], in line with the answers of our respondents, sharing knowledge with colleagues is not correlated with either employment in online business or with employment, in general, and thus hypotheses H2a and H2b (details in Table 4) have been rejected. The students' knowledge provided to colleagues does not guarantee any effect of supporting their own employability through exchanges of reflections, ideas, impressions and so on. We consider this behaviour as being a sign of a climate of a very weak orientation towards the sharing of useful professional knowledge among students in the online environment. Despite the fact that e-learning represents a very important factor for employability [31,36], in online business education, students should behave as active knowledge seekers [28]. Knowledge sharing, in the case of students, involves the online co-learning, and this means exchanges of comments and also feedback and other types of knowledge dissemination [39], however the results show that knowledge sharing does not have an influence on business students' perception of their chances of employment and, respectively, on their chances of employment in online businesses. In another study conducted recently, it has been shown that the number of those who never worked in groups increased during the pandemic, the percentage of those who never studied together with other colleagues increased and the percentage of students requesting help from colleagues decreased [42], which is an additional argument of the fact that a possible explanation would be a climate of a very weak orientation towards the sharing of useful professional knowledge among students in the online environment.

The logistic regression results also show that business students' perception of their chances of employment is negatively and significantly influenced by knowledge acquisition (details in Table 6). Therefore, hypothesis H1a has been rejected. In the context of online employment, no significant results have been found, thus rejecting H1b. Although several studies [35] consider knowledge acquisition to be an important determinant helping students build higher-order thinking skills and improving students' ability to construct their own knowledge [35] (pp.21-22), our study confirmed a surprising result: knowledge acquisition in the context of online studies is not well-perceived by students from the perspective of their employability. Students consider that the orientation towards knowledge acquisition, in the conditions when the scores for knowledge application and revision of the old mental models remain constant, decreases their chances of employment. The results obtained in the case of knowledge acquisition are even more surprising if we consider the fact that, in the literature in the field of knowledge management, the first stage in the processing cycle of knowledge is knowledge acquisition [25]. In order to obtain a positive correlation between knowledge acquisition and business students' perception of their chances of employment, and respectively, business students' perception of their chances of employment in online businesses, a potential solution would be for students to learn more from real world situations. Thus, more resources ought to be invested in technology and especially in business simulations technology [35] (p.23). The process of knowledge acquisition can be considered of high importance, since, based on the literature review undertaken, we can consider it to be the foundation of many other knowledge management processes (knowledge sharing, revision of knowledge and conceptual change, knowledge application, etc.). 
The results also indicate that business students' perception of their chances of employment is positively influenced by the revision of knowledge and conceptual change, therefore validating hypothesis H3a (details in Table 6). However, in terms of online business employment, revision of knowledge and conceptual change does not represent a significant determinant, and thus, H3b has been rejected (details in Table 6). In order to improve their employability, students need to better manage the revision of their thought patterns and the application of knowledge [32,49]. Students experience knowledge revisions and conceptual changes in the classroom, during online courses, or by chatting with colleagues; students can prove that they are creative, innovative and have original thinking [32]. The individual management of students' knowledge, with a higher probability of supporting employability, depends on the revision of students' thought patterns in the context of making online courses.

Management of one's own knowledge, with a higher probability of supporting employability, depends on the application of the acquired knowledge by students in the context of doing online studies. When a person who learns utilizes the existing knowledge that they have, it is considered that knowledge application occurs [12]. Logistic regression results indicate that business students' perception of their chances of employment, in general, and in online businesses, in particular, are positively influenced by knowledge application, thus validating hypotheses H4a and H4b (details in Table 6). The outcomes indicate that knowledge application represents an important determinant of students' propensity to be hired, either in general or in online businesses. In the case of online employability, students recognize the influence of a single variable related to the management of their own knowledge: knowledge application. Neither the acquisition of knowledge, nor the revision of knowledge, are considered by students as influencing their employability in online businesses. Therefore, when students apply the knowledge that they gained, the highest possible value is conferred to their knowledge, from an employer's point of view. Nentl and Zietlow (2008) [57] (p. 162) and Brînză et al. (2020) [59] studies also indicate that knowledge application is highly linked, for students, with the chances of being successfully employed.

To summarise, we have found that students connect the dependence of their success in employment to how they manage to adapt their mental patterns and apply what they have learned. Second, we have noticed that students do not recognize a positive dependency relationship between the acquisition of knowledge through online education and employability. This is an important negative signal about the usefulness and the format of knowledge they are currently acquiring through this type of education. Third, we have found that the chances of employment in online businesses are not supported by students current knowledge management model, only knowledge application being accepted as influencing employability. Knowledge acquisition and reviewing thought patterns (knowledge revision and conceptual change) are not seen by students as having an influence on their chances of employment in online businesses. This can be translated into an awareness of the mismatch between what knowledge they acquire and what patterns of thinking they are currently forming through these online classes, and respectively, the requirements they will have to meet in order to become employed. Despite the accepted consequence of lowering the ecological footprint of the campus [5], the e-learning regime does not seem to ensure sustainability at the level of the knowledge management of students and their perception about employability.

\section{Conclusions}

The aim of our study was to analyse knowledge management of business students in an online education setting in order to discover its influence on students' perception of both their general employment chances, and specifically, in online businesses. The study was based on a quantitative analysis using a questionnaire-based survey, which included a sample of 256 valid responses. The survey only included bachelor students in their final year of study and master students, as they are more preoccupied with their em- 
ployment opportunities, and more active in the labour market compared to their peers. The survey respected the anonymity of the respondents, and no personal information has been gathered.

Two research questions derived from the aim of the study: Have business students adapted their ways of managing knowledge for online education in a manner that supports their chances of employment, in general, and in online businesses, in particular?; Have the ways of managing their knowledge during online education made business students better prepared for employability in online businesses?

In line with the research hypotheses, correlation, reliability tests and logistic regression were used to perform data analysis and the results obtained for these analyses have been thoroughly presented in a previous section.

To reach the objective of our study and to answer the research questions, we developed our analysis based on a model of students' knowledge management found in Chang et al. (2013), who used five dimensions in order to define the way students manage their knowledge while studying: knowledge sharing, knowledge innovation, knowledge acquisition, knowledge application and knowledge accumulation [12]. We excluded knowledge accumulation, since we considered it to be too similar-for an unprepared respondent- to knowledge acquisition, thus we adopted only four variables from Chang et al.'s (2013) model [12]. The variable knowledge innovation was renamed and appears throughout this paper as knowledge revision and conceptual change; the questions for this scale were adapted accordingly. When we refer to the ways that students manage their knowledge during their online studies, we thus need to take into consideration these four knowledge management processes-knowledge acquisition, knowledge sharing, knowledge revision and conceptual change and knowledge innovation-and discover the influences on students' perception of both their general employment chances, and specifically in online businesses.

The correlation analysis indicates no association between knowledge sharing and students' chances of employment, in general, and in online businesses, in particular, therefore the construct has been eliminated from the logistic regression analysis. The reliability tests showed high values for knowledge revision and conceptual change, knowledge acquisition and application, which indicate that all three items have a relatively high internal consistency, and remained in the analysis.

Several logistic regressions have been performed in order to validate the assumed hypothesis and to assess whether business students adapted their ways of managing knowledge for online education in a manner that supports their chances of employment, and also to establish if the ways of managing their knowledge during online education made business students better prepared for employment in online businesses.

In the case of business students' perception of their chances of employment, all three independent variables, both independently and under the action of control variables, had a significant influence. The analyses show that revision of knowledge and conceptual change and knowledge application had a significant impact on business students' perception of their chances of employment. The analyses also show that business students' perception of their chances of employment was significantly but inversely influenced by knowledge acquisition. For these aspects, we can think of the following possible causes: (1) students do not find online knowledge acquisition very attractive, so they do not view it as helpful for their employment; (2) students find more interesting knowledge application in the non-online working environment for raising their chances of getting a job.

Regarding the probability that online studies improve students' chances of employment in an online business, evidence shows that only knowledge application has a significant impact on this dependent variable, and this happens both when no control variables are considered and when control variables are considered. The probability that online studies improve students' chances of employment in an online business was significantly influenced by knowledge application. This means that, even if the employability is in online 
businesses, the application of knowledge is the most important factor that could increase students' perception of employability in the labour market.

Considering the obtained results, we can conclude that: business students did not adapt their knowledge acquisition process in online education in a manner that positively influences business students' perception of their chances of employment; regarding business students' perception of their chances of employment in online businesses, we found no significant results either, thus also highlighting a lack of adaptation in the business students' knowledge acquisition process in the context of online education. Problems regarding business students' adaptation in managing their knowledge, in the context of online education, in order to positively influence their perception regarding their chances of employment in general and in online businesses in particular can be found also in the case of knowledge sharing (no significant correlations have been found with either of the dependent variables). Knowledge revision and conceptual change is a process that business students managed to adapt in the context of online education in order to increase their chances of employment in general, but did not manage to adapt in order to increase their chances in employment in online businesses. The best situation regarding business students' adaptation in online education is in the case of knowledge application. This knowledge management process has a positive influence on both employment in general and employment in online business. Thus, business students partially adapted their ways of managing knowledge for online education in a manner that supports their chances of employment, in general, and in online businesses in particular. We can assume that business students are better prepared, in the context of online education, for employment in general compared to employment in online businesses. Knowledge management of business students in online education setting has an influence on students' perception of their general employment chances, and specifically in online businesses, but not all of the knowledge management processes considered in this paper have a positive influence on either employment in general or on employment in online businesses in particular.

Two main contributions of our paper are the fact that we compared two different ways of employment for students - the classic way of employment, for working on-site, and the online employment, for working using various IT\&C online systems-and the fact that we have analysed knowledge management of business students within the context of online education.

\section{Limitations and Future Research}

Of course, this study has several limitations. Two of the most important limitations of our study are the fact that we have applied the questionnaire to students from only one Faculty in Romania, and all the students that responded to the questionnaire had been previously familiar only to courses and seminars, which had been held in the classroom, and not online (until the spring of 2020), thus, by the time they completed the survey, they had accumulated little experience regarding online learning (less than two semesters). Therefore, the results cannot be generalized to all students from faculties of economics and / or business administration in Romania, even though most Romanian faculties in the field of economics and business administration started their online experiences not earlier than March 2020, when the COVID-19 pandemic imposed the necessity of online run classes. Secondly, more faculties of Economics and Business Administration from Romania, or even in other countries, could be taken into consideration, which would also allow comparisons between the adaptations of students' ways of managing knowledge for online education, in a manner that supports their chances of employment, in general, and in online businesses, in particular.

Additionally, due to time constraints, which led to some difficulties concerning data collection, the only consideration regarding the sample was that the respondents had to be either in the final year of the undergraduate level, or at the master level. Besides this consideration, no sample scheme was considered, and thus the results cannot be generalized. 
Further, our study is cross-sectional, so future research could consider longitudinal studies as well, in order to see an evolution of the students' ways of managing knowledge for online education. Of course, for these kinds of studies to be possible, longer periods of online studies would need to be possible.

Ultimately, the size of our sample, namely 256 students that responded to the questionnaire, implies the need to treat the results with caution. Therefore, in future research, larger samples could be considered.

Author Contributions: The authors' contributions were equal. Conceptualization, Ş.A.N., A.I.V., S.M.T., A.L.G. and E.-S.T.; methodology, A.I.V.; statistical method and analysis, A.I.V.; writingoriginal draft preparation, Ş.A.N., A.I.V., S.M.T., A.L.G. and E.-S.T.; writing-review and editing, S.A.N., A.I.V., S.M.T., A.L.G. and E.-S.T.; project administration, S..A.N., S.M.T., A.L.G. and E.-S.T. All authors have read and agreed to the published version of the manuscript.

Funding: This research received no external funding.

Institutional Review Board Statement: Not applicable.

Informed Consent Statement: Not applicable.

Data Availability Statement: Not applicable.

Conflicts of Interest: The authors declare no conflict of interest.

\section{References}

1. Tarabasz, A.; Selaković, M.; Abraham, C. The Classroom of the Future: Disrupting the Concept of Contemporary Busi-ness Education. Entrep. Bus. Econ. Rev. 2018, 6, 231-245. [CrossRef]

2. Dhamdhere, S.N. Knowledge Management Model for Higher Educational Institutes. J. Commer. Manag. Thought 2015, 6, 130. [CrossRef]

3. Salvioni, D.M.; Franzoni, S.; Cassano, R. Sustainability in the higher education system: An opportunity to improve quality and image. Sustainability 2017, 9, 914. [CrossRef]

4. Trencher, G.; Nagao, M.; Chen, C.; Ichiki, K.; Sadayoshi, T.; Kinai, M.; Kamitani, M.; Nakamura, S.; Yamauchi, A.; Yarime, M.; et al. Implementing Sustainability Co-Creation between Universities and Society: A Typology-Based Understanding. Sustainability 2017, 9, 594. [CrossRef]

5. Caeiro, S.; Sandoval Hamon, L.A.; Martins, R.; Bayas Aldaz, C.E. Sustainability assessment and benchmarking in higher education institutions-A critical reflection. Sustainability 2020, 12, 543. [CrossRef]

6. Silveira, C.; Reis, L. Sustainability in Information and Communication Technol-ogies. In Handbook of Research on Multidisciplinary Approaches to Entrepreneurship, Innovation, and ICTs; IGI Global: Hershey, PA, USA, 2021; pp. 375-396.

7. Ruiz-Mallén, I.; Heras, M. What sustainability? Higher education institutions' pathways to reach the Agenda 2030 goals. Sustainability 2020, 12, 1290. [CrossRef]

8. Nilsook, P.; Sriwongkol, T. The Development of Multi-Weblog with Knowledge Management for Thailand's Higher Education. In Proceedings of the International Conference on Information and Multimedia Technology, Jeju Island, Korea, 16-18 December 2009; IEEE: New York, NY, USA, 2009; pp. 315-319.

9. Paudel, K.P. Expectations and Realities of Knowledge Management: Experiences from Higher Education in Developing Countries. Educ. Dev. 2019, 29, 89-102.

10. Gamlath, S.; Wilson, T. Knowledge Sharing among University Students: A Review of Current Practices. 2017. Available online: https: / / ssrn.com/abstract=2962616 (accessed on 7 January 2021).

11. Pattnayak, J.; Pattnaik, S.; Dash, P. Knowledge Management in E-Learning A Critical Analysis. Int. J. Eng. Sci. 2017, 6, 21528-21533. [CrossRef]

12. Chang, C.C.; Tseng, K.H.; Liang, C.; Chen, T.Y. Using e-portfolios to facilitate university students' knowledge management performance: E-portfolio vs. non-portfolio. Comput. Educ. 2013, 69, 216-224.

13. Avramenko, A. Enhancing students' employability through business simulation. J. Educ. Train. 2012, 54, 355-367. [CrossRef]

14. Rae, D. Connecting enterprise and graduate employability: Challenges to the higher education culture and curriculum? J. Educ. Train. 2007, 49, 605-619. [CrossRef]

15. Sewell, P.; Pool, L.D. Moving from conceptual ambiguity to operational clarity: Employability, enterprise and entrepreneurship in higher education. J. Educ. Train. 2010, 52, 89-94. [CrossRef]

16. Harvey, L.; Moon, S.; Geall, V. Graduates Work: Organisational Change and Students Attributes. Available online: http: //heer.qaa.ac.uk/SearchForSummaries/Summaries/Pages/GLM48.aspx (accessed on 21 January 2021).

17. Dacre Pool, L.; Sewell, P.J. The key to employability: Developing a practical model of graduate employability. J. Educ. Train. 2007, 49, 277-289. [CrossRef] 
18. Neubaum, D.O.; Pagell, M.; Drexler, J.A.; Mckee-Ryan, F.M.; Larson, E. Business education and its relationship to student personal moral philosophies and attitudes toward profits: An empirical response to critics. Acad. Manag. Learn. Educ. 2009, 8, 9-24. [CrossRef]

19. Turnea, E.-S.; Neștian, Ș.A.; Tiță, S.M.; Vodă, A.I.; Guță, A.L. Dismissals and Temporary Leaves in Romanian Companies in the Context of Low Demand and Cash Flow Problems during the COVID-19 Economic Lock-down. Sustainability 2020, 12, 8850. [CrossRef]

20. Brewer, P.D.; Brewer, K.L. Knowledge Management, Human Resource Management, and Higher Education: A Theoretical Model. J. Educ. Bus. 2010, 85, 330-335. [CrossRef]

21. Voda, A.I.; Florea, N. Impact of Personality Traits and Entrepreneurship Education on Entrepreneurial Intentions of Business and Engineering Students. Sustainability 2019, 11, 1192. [CrossRef]

22. So, H.J.; Brush, T.A. Student perceptions of collaborative learning, social presence and satisfaction in a blended learning environment: Relationships and critical factors. Comput. Educ. 2008, 51, 318-336.

23. Pellegrini, M.M.; Ciampi, F.; Marzi, G.; Orlando, B. The relationship between knowledge management and leadership: Mapping the field and providing future research avenues. J. Knowl. Manag. 2020, 24, 1445-1492. [CrossRef]

24. Wach, K.; Głodowska, A.; Maciejewski, M. Entrepreneurial Orientation, Knowledge Utilization and Internationalization of Firms. Sustainability 2018, 10, 4711.

25. Chi, M.T.H.; Roscoe, R. The processes and challenges of conceptual change. In Reconsidering Conceptual Change: Issues in Theory and Practic; Limon, M., Mason, L., Eds.; Kluwer Academy Publishers: Amsterdam, The Netherlands, $2002 ;$ pp. 3-27.

26. Al-Emran, M.; Teo, T. Do knowledge acquisition and knowledge sharing really affect e-learning adoption? An empirical study. Educ. Inf. Technol. 2019, 25, 1-16. [CrossRef]

27. Vătămănescu, E.M.; Andrei, A.G.; Dumitriu, D.L.; Leovaridis, C. Harnessing network-based intellectual capital in online academic networks. From the organizational policies and practices towards competitiveness. J. Knowl. Manag. 2016, 20, 594-619. [CrossRef]

28. Bratianu, C.; Hadad, S.; Bejinaru, R. Paradigm Shift in Business Education: A Competence-Based Approach. Sustainability 2020, 12, 1348. [CrossRef]

29. Brãtianu, C.; Neştian, A.Ş.; Tiţã, S.M.; Vodã, A.I.; Guţã, A.L. The impact of knowledge risk on sustainability of firms. Amfiteatru Econ. 2020, 22, 639-652. [CrossRef]

30. Arpaci, I.; Al-Emran, M.; Al-Sharafi, M.A. The impact of knowledge management practices on the acceptance of Massive Open Online Courses (MOOCs) by engineering students: A cross-cultural comparison. Telemat. Inform. 2020, 54. [CrossRef]

31. Silva, A.P.; Lourtie, P.; Aires, L. Employability in Online Higher Education: A Case Study. Available online: http://www.irrodl. org/index.php/irrodl/article/view/1262/2426 (accessed on 19 January 2021).

32. Bell, R. Unpacking the link between entrepreneurialism and employability: An assessment of the relationship between entrepreneurial attitudes and likelihood of graduate employment in a professional field. J. Educ. Train. 2016, 58, 2-17. [CrossRef]

33. Turnea, E.S.; Prodan, A. The Relative Influence of Total Reward on Retention of Human Resources. RCIS 2020, 69, 79-95. [CrossRef]

34. Di Prete, T.A.; Goux, D.; Maurin, E.; Tåblin, M. Institutional Determinants of Employment Chances. The Structure of Unemployment in France and Sweden. Eur. Sociol. Rev. 2001, 17, 233-254. [CrossRef]

35. Tseng, H.; Yi, X.; Yeh, H.T. Learning-related soft skills among online business students in higher education: Grade level and managerial role differences in self-regulation, motivation, and social skill. Comput. Hum. Behav. 2019, 95, 179-186. [CrossRef]

36. Martínez-Cerdà, J.F.; Torrent-Sellens, J. E-learning, e-skills and employability: First evidence in European countries. eLC Res. Pap. Ser. 2014, 9, 6-14.

37. Liu, C.-C.; Lin, C.-C.; Chang, C.-Y.; Chao, P.-Y. Knowledge Sharing among University Students Facilitated with a Creative Commons Licensing Mechanism: A Case Study in a Programming Course. J. Educ. Techno. Soc. 2014, 17, $154-167$.

38. Cabrera, A.; Cabrera, E.F. Knowledge-sharing dilemmas. Organ. Stud. 2002, 23, 687-710. [CrossRef]

39. Okada, A.; Shum, S.B.; Bachler, M.; Tomadaki, E.; Scott, P.; Little, A.; Eisenstadt, M. Knowledge media tools to foster social learning. In Social Computing: Concept, Methodologies, Tools and Applications; IGI Global: Hershey, PA, USA, 2010 ; pp. 864-884.

40. Yuen, T.J.; Majid, S.M. Knowledge-sharing patterns of undergraduate students in Singapore. Libr. Rev. 2007, 56. [CrossRef]

41. Högberg, C.; Edvinsson, L. A design for futurizing knowledge networking. J. Knowl. Manag. 1998, 2, 81-92.

42. Lup, O.; Mitrea, E.C. Învățământul Universitar din România în Contextul Pandemiei COVID-19 Experiențele Studenților. EDITURA INSTITUTULUI DE CERCETARE FĂGĂRAȘ. Available online: https: / /www.edupedu.ro/cursurile-online-care-voravea-un-loc-central-in-noul-an-universitar-au-fost-percepute-de-majoritatea-studentilor-drept-mai-rele-sau-mult-mai-reledecat-cele-fata-in-fata-in-primavara-prea-multe-p/ (accessed on 20 January 2021).

43. Dwiyanti, W. The Stage's of Sharing Knowledge among Students in Learning Environment: A Review of Literature. Int. J. Educ. Res. 2017, 5, 81-92.

44. Aljaaidis, K.S.; Bagais, O.A.; Al-Moataz, E. Knowledge sharing and individuals' effectiveness in educational institutions. Manag. Sci. Lett. 2020, 10, 3477-3484. [CrossRef]

45. How Graduates Can Get Hired during the Coronavirus Pandemic 2020. Available online: https:/ /www.topuniversities.com/ student-info/careers-advice/how-graduates-can-get-hired-during-coronavirus-pandemic (accessed on 25 January 2021).

46. Seaman, A. The Skills Employers Want most during the Pandemic. Available online: https://www.linkedin.com/pulse/skillsemployers-want-most-during-pandemic-andrew-seaman (accessed on 26 January 2021). 
47. Zhan, Q. A Model for Knowledge Innovation in Online Learning Community Edutainment Conference: Technologies for E-Learning and Digital Entertainment. Proceedings of Third International Conference, Edutainment 2008, Nanjing, China, 25-27 June 2008; pp. 21-31.

48. Thomas, C.L.; Kirby, L.A. Situational interest helps correct misconceptions: An investigation of conceptual change in university students. Instruct. Sci. Int. J. Learn. Sci. 2020, 48, 223-241. [CrossRef]

49. Kendeou, P.; Walsh, E.K.; Smith, E.R.; O’Brien, E.J. Knowledge revision processes in refutation texts. Discourse Process. 2014, 51, 374-397. [CrossRef]

50. Chiva, R.; Grandio, A.; Alegre, J. Adaptive and Generative Learning: Implications from Complexity Theories. Int. J. Manag. Rev. 2010, 12, 114-129. [CrossRef]

51. Sharp, D.C.; Knowlton, D.S.; Weiss, R.E. Applications of Generative Learning for the Survey of International Economics Course. J. Econ. Educ. 2005, 36, 345-357. [CrossRef]

52. Guță, A.L. Education for The Knowledge Society, Education for a Free Society. Available online: https://papers.ssrn.com/sol3 / papers.cfm?abstract_id=2443483 (accessed on 28 January 2021).

53. Trevors, G.J.; Kendeou, P.; Bråten, I.; Braasch, J.L. Adolescents' epistemic profiles in the service of knowledge revision. Contemp. Educ. Psychol. 2017, 49, 107-120. [CrossRef]

54. Trevors, G.J.; Muis, K.R.; Pekrun, R.; Sinatra, G.M.; Winne, P.H. Identity and Epistemic Emotions During Knowledge Revision: A Potential Account for the Backfire Effect. Discourse Process. 2016, 53, 339-370. [CrossRef]

55. Grandzol, J.R.; Grandzol, C.J. Best Practices for Online Business Education. Int. Rev. Res. Open Distrib. Learn. 2006, 7, 1-18. [CrossRef]

56. Tiwari (Mishra), S. Skills, competencies and employability through business education. J. Manag. Res. 2012, 6, 1-13. Available online: https:/ /apps.aima.in/ejournal_new/articlesPDF/DrShwetaTiwari_Article.pdf (accessed on 26 January 2021).

57. Nentl, N.; Zietlow, R. Using Bloom's Taxonomy to Teach Critical Thinking Skills to Business Students. Coll. Undergrad. Libr. 2008, 15, 159-172. [CrossRef]

58. Karyaningsih, R.P.D.; Wibowo, A.; Saptono, A.; Narmaditya, B.S. Does entrepreneurial knowledge influence vocational students' intention? Lessons from Indonesia. Entrep. Bus. Econ. Rev. 2020, 8, 138-155. [CrossRef]

59. Brînză, G.; Anichiti, A.; Butnaru, G.I. Perceptions of the Students in the Tourism Specialisations Regarding the Effectiveness of the Educational Process and Their Preparation for the Tourism Sector. In Proceedings of the 6th BASIQ International Conference on New Trends in Sustainable Business and Consumption, Messina, Italy, 4-6 June 2020; Pamfilie, R., Dinu, V., Tăchiciu, L., Pleșea, D., Vasiliu, C., Eds.; ASE: Bucharest, Romania, 2020; pp. 137-144.

60. Shea, P.; Pickett, A.; Li, C.S. Increasing access to Higher Education: A study of the diffusion of online teaching among 913 college faculty. Int. Rev.Res. Open Distance Learn. 2005, 6, 1-27. [CrossRef]

61. Cerny, C.A.; Kaiser, H.F. A study of a measure of sampling adequacy for factor-analytic correlation matrices. Multivariate Behav Res. 1977, 12, 43-47. [PubMed]

62. Gravetter, F.J.; Wallnau, L.B. Statistics for Behavioral Science, 7th ed.; Thomson Wadsworth: Belmont, CA, USA, 2008. 